\title{
Correction of glutathione deficiency in the lower respiratory tract of HIV seropositive individuals by glutathione aerosol treatment
}

Kenneth J Holroyd, Roland Buhl, Zea Borok, James H Roum, Allan D Bokser, George J Grimes, Dorothy Czerski, Andre M Cantin, Ronald G Crystal

\begin{abstract}
Background-Concentrations of glutathione, a ubiquitous tripeptide with immune enhancing and antioxidant properties, are decreased in the blood and lung epithelial lining fluid of human immunodeficiency virus (HIV) seropositive individuals. Since the lung is the most common site of infection in those who progress to AIDS it is rational to consider whether it is possible to safely augment glutathione levels in the epithelial lining fluid of HIV seropositive individuals, thus potentially improving local host defence.

Methods-Purified reduced glutathione was delivered by aerosol to HIV seropositive individuals $(n=14)$ and the glutathione levels in lung epithelial lining fluid were compared before and at one, two, and three hours after aerosol administration.
\end{abstract}

Results-Before treatment total glutathione concentrations in the epithelial lining fluid were approximately $60 \%$ of controls. After three days of twice daily doses each of $600 \mathrm{mg}$ reduced glutathione, total glutathione levels in the epithelial lining fluid increased and remained in the normal range for at least three hours after treatment. Strikingly, even though $\mathbf{7 9 5 \%}$ of the glutathione in the aerosol was in its reduced form, the percentage of oxidised glutathione in epithelial lining fluid increased from $5 \%$ before treatment to about $\mathbf{4 0 \%}$ three hours after treatment, probably reflecting the use of glutathione as an antioxidant in vivo. No adverse effects were observed.

Conclusions-It is feasible and safe to use aerosolised reduced glutathione to augment the deficient glutathione levels of the lower respiratory tract of HIV seropositive individuals. It is rational to evaluate further the efficacy of this tripeptide in improving host defence in HIV seropositive individuals.

(Thorax 1993;48:985-989)

A major manifestation of AIDS is opportunistic infections in the lung. ${ }^{2}$ While depletion of $\mathrm{CD} 4+\mathrm{T}$ cells plays an important part in the

pathogenesis of AIDS, the extent of immune abnormalities in healthy HIV seropositive individuals with normal numbers of CD4+ $T$ cells suggests that there must be additional mechanisms contributing to the immune dysfunction associated with HIV infection. ${ }^{3-5}$

One such mechanism may be the observed deficiency of the antioxidant and immune enhancing tripeptide glutathione ( $\mathrm{L}-\gamma-\mathrm{glu}-$ tamyl-L-cysteinyl-glycine) ${ }^{67}$ In symptom free HIV seropositive individuals, glutathione levels in plasma are approximately $30 \%$, and in respiratory epithelial lining fluid are approximately $60 \%$ of those measurable in normal individuals. ${ }^{8}$ As an antioxidant which efficiently scavenges toxic oxygen radicals (oxidants), a deficiency of reduced glutathione may lead to a loss of immune cell function..$^{9-11}$ As a metabolite or cofactor in several normal immune cell processes, a deficiency of reduced glutathione causes dysfunction of lymphocytes and natural killer cells. ${ }^{12-15}$ In addition, recent observations suggest that intracellular glutathione deficiency may permit more rapid growth of the HIV virus. ${ }^{16-18}$ The importance of glutathione as an antioxidant and for host defence, particularly in the lung, is further emphasised by its concentration in normal lung epithelial lining fluid which is more than 40 times greater than that of plasma. ${ }^{19} 20$

With this background it is reasonable to consider administering glutathione to augment its levels in individuals with HIV infection. Since oral administration would lead to gastric degradation by peptidases, and since intravenous administration is impractical because its serum half life is less than two minutes, ${ }^{21}$ we have developed a strategy of targeting glutathione to the lung using aerosol delivery in an animal model..$^{22}$ Armed with this knowledge, we have evaluated the feasibility of augmenting levels of glutathione in the lung epithelial lining fluid in HIV seropositive individuals by aerosol.

\section{Methods}

STUDY POPULATION

Fourteen HIV seropositive individuals (13 men, mean (SE) age 32 (2) years) were studied. The diagnosis of HIV infection was confirmed by ELISA and Western blot analysis. All patients belonged to defined risk groups (13 homosexuals, one with a history of heterosexual contact with an infected

Returned to auther

22 July 1992

Revised version received

Accepted 13 July 1993 
partner). None were smokers. Nine were untreated; five were receiving azidothymidine, and two were receiving pentamidine once a month by aerosol. Because of the small numbers, no attempt was made to analyse a potential drug effect on glutathione metabolism. The mean (SE) number of blood lymphocytes was 1430 (170) cells $/ \mu \mathrm{l}$, including 279 (53) CD4+ lymphocytes/ $\mu$ l. p24 antigen was detected in the sera of two individuals. All had normal chest radiographs. Results of lung function tests were within the normal ranges.

To evaluate possible toxicity of the glutathione aerosol, symptoms, physical examination, routine blood studies, chest radiograph, electrocardiogram, renal function, arterial blood gases, and tests of pulmonary function (forced vital capacity, forced expiratory volume in one second, total lung capacity, diffusing capacity) were followed carefully throughout the study. In addition, visual examination of the respiratory mucosa and analysis of differential cell count in bronchoalveolar lavage fluid were performed before the first and after the last aerosol doses.

All subjects gave informed consent for the study, including bronchoalveolar lavage. The study protocol (89-H-118) was approved by the Institutional Review Board of the National Heart, Lung, and Blood Institute, and the US Food and Drug Administration (IND 33-378).

\section{BIOLOGICAL SAMPLES}

Venous plasma and bronchoalveolar lavage fluid samples were obtained using standard techniques. ${ }^{23}$ Portions of the lavage fluid were taken for glutathione assay (see below), cell counts (total cell and CD4 + and CD8+ subtypes), and for cytocentrifuge preparations for differential counts. The cells were pelleted and the supernatant used to quantify the amount of epithelial lining fluid recovered by the urea method. ${ }^{24}$

\section{GLUTATHIONE PREPARATION}

The reduced form of glutathione was obtained as a free acid (tissue culture grade; Sigma) and stored at $4^{\circ} \mathrm{C}$. All preparations were sterile and pyrogen-free as determined by the NIH Pharmaceutical Development Service. The glutathione preparation was $>98 \%$ pure. The percentage of reduced glutathione determined before each experiment (see below) was constantly $>96 \%$.

\section{STUDY DESIGN}

Venous plasma and bronchoalveolar lavage fluid were obtained before administration of reduced glutathione. An aerosol of $600 \mathrm{mg}$ reduced glutathione in $4 \mathrm{ml}$ saline was then administered over a 25 minute period twice a day for three days. All subjects inhaled whilst sitting upright. Bronchoalveolar lavage fluid was again obtained one hour after the last aerosol in six individuals, and two and three hours after the last aerosol in four individuals. Venous plasma was again obtained one hour after the last reduced glutathione aerosol. All measurements were made in duplicate.

\section{AEROSOL GENERATING SYSTEM}

Reduced glutathione was aerosolised using a nebuliser (Ultravent, Mallinckrodt) that generates aerosol droplets of a size capable of reaching the lower respiratory tract. ${ }^{22}$ To generate the aerosol containing the reduced glutathione, $4 \mathrm{ml}$ of a solution of reduced glutathione at a concentration of $150 \mathrm{mg} / \mathrm{ml}$ in $0.9 \% \mathrm{NaCl}$ was placed in the reservoir of the nebuliser and the nebuliser was driven at 40 psi with compressed air. The size distribution of aerosol droplets determined by laser particle size analysis showed a mass median aerodynamic diameter of the droplets of $2 \cdot 8$ $\mu \mathrm{m}$ with a geometric standard deviation of $1.3 \mu \mathrm{m}$. To rule out the possibility that reduced glutathione is oxidised by the aerosolisation process or during the lavage procedure, reduced glutathione was aerosolised, the aerosol droplets collected in of vitro, and the lavage equivalent carried out through the bronchoscope at the laboratory bench. No oxidation was observed in that the relative proportion of the reduced glutathione preparation remaining in the reduced form was unchanged. ${ }^{22}$ The total glutathione in the pre-aerosol preparations therefore contained $98.2 \%(0.1 \%)$ glutathione in the reduced form, while the glutathione in the aerosolised droplets was $97.0 \%(0.6 \%)$ in the reduced form. The aerosol was therefore composed of fully functional reduced glutathione contained within droplets of an optimal size for reaching the epithelial surface of the lower respiratory tract.

\section{GLUTATHIONE LEVELS AND FORM}

Glutathione levels in venous plasma and bronchoalveolar lavage fluid were quantified using standard methods with minor modifications as previously described. ${ }^{81922}$

\section{T LYMPHOCYTE PROLIFERATION ASSAYS}

Cell proliferation in the presence of concen- $\frac{\text { O }}{3}$ trations of reduced glutathione before and $\frac{D}{O}$ after treatment was tested on the cytotoxic $T$ ․․ lymphocyte cell lines CT-4R and CTLL-2. ${ }^{14} \mathrm{~N}$ A total of 50000 cells of the respective cell $N$ lines, suspended in $200 \mu \mathrm{l}$ Dulbecco's N Modified Eagle Medium with $10 \%$ fetal calf serum, with either $150 \mu \mathrm{mol} / 1$ or $280 \mu \mathrm{mol} / 1$ ? reduced glutathione added, were placed in 96-well flat bottom plates. The IL-2 depen- $\stackrel{0}{\rightarrow}$ dent cell line CTLL-2 had 0.3 units $/ \mathrm{ml} \mathrm{IL-2}$ (Genzyme) added in each well. After 18 웅 hours culture in a $10 \%$ carbon dioxide incu- $\stackrel{\mathbb{D}}{\circ}$

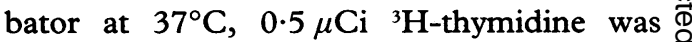
added for four hours followed by harvesting of cells onto glass fibre filters and scintillation counting for one minute. All proliferation $\frac{8}{0}$ assays were performed in triplicate.

\section{STATISTICAL ANALYSIS}

All data are presented as mean (SE); all statistical comparisons were made using the two tailed Student's $t$ test. 
Figure 1 Concentration of total glutathione in $\mu$ moll in lung epithelial lining fluid (ELF) before and at one, two, and three hours after the final aerosol of $600 \mathrm{mg}$ reduced glutathione (GSH) administered once every 12 hours for three days. The shaded region represents the normal range of total glutathione in $E L F$.

Values at one, two, and three hours are significantly greater than the pre-aerosol value $(p<0.005)$.

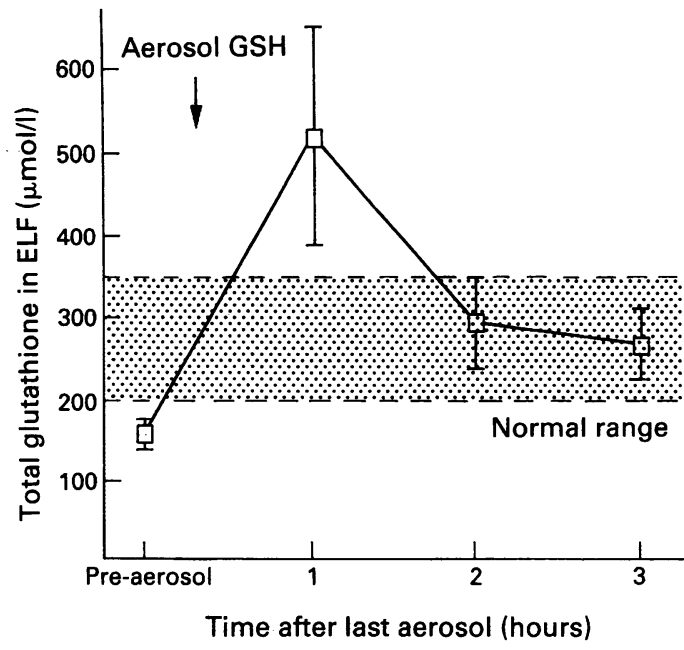

\section{Results}

SAFETY EVALUATION

No symptoms referable to the aerosol administration of glutathione were noted, and physical examination and all clinical measurements remained stable following treatment with glutathione. Pulmonary function tests and arterial blood gases were also unchanged (all indices $\mathrm{p}>0.3$ compared with baseline). Aerosolisation of reduced glutathione did not cause inflammation of the lower respiratory tract as judged by visual inspection of the mucous membranes, measurements of volumes of epithelial lining fluid in bronchial lavage fluids before and after aerosol administration, or lavage differential cell count (all comparisons $\mathrm{p}>0 \cdot 1$ compared with baseline values).

\section{GLUTATHIONE LEVELS BEFORE AND AFTER} AEROSOLISATION

Before treatment total glutathione levels in the epithelial lining fluid of the HIV seropositive group were significantly below normal.
After six doses of $600 \mathrm{mg}$ reduced glutathione given every 12 hours for three days, however, total glutathione values in the epithelial lining fluid rose above the pretreatment value in each of the 14 individuals evaluated to a mean value above or within the normal range. Levels remained increased for at least three hours - that is, the half life of glutathione in epithelial lining fluid is much longer than in plasma ${ }^{21}$ - suggesting independence of respiratory epithelial lining fluid and plasma with regard to glutathione metabolism (fig 1).

As with total glutathione, the mean levels of reduced glutathione in epithelial lining fluid in the HIV seropositive group were significantly below normal. Following three days of aerosol treatment reduced glutathione levels in the epithelial lining fluid entered the normal range at one hour and at two hours, returning to baseline levels at three hours (fig 2A). Thus, as expected, before treatment $95 \%(2 \%)$ of the total glutathione recovered from epithelial lining fluid was in the reduced form. After treatment reduced glutathione levels in epithelial lining fluid at each time point were significantly lower than levels of total glutathione (compare fig 2A with fig 1; $\mathrm{p}<0.05$, comparisons at all time points after treatment). This difference is explained by a dramatic increase in both the absolute amounts and the percentage of oxidised glutathione in epithelial lining fluid after treatment. The mean level of oxidised glutathione in epithelial lining fluid rose considerably after treatment and remained elevated during the study period (table). Expressed as a percentage of total glutathione in epithelial lining fluid at, for example, three hours, when reduced glutathione had returned to pretreatment levels oxidised glutathione represented $44 \%(18 \%)$ of the total glutathione in epithelial lining fluid (fig 2B)

Glutathione levels in venous plasma did not change significantly during the study period (table).

Mean (SE) glutathione levels in HIV seropositive individuals before and after glutathione aerosol treatment (six doses of $600 \mathrm{mg}$ glutathione administered 12 hourly for three days)

\begin{tabular}{|c|c|c|c|}
\hline & $\begin{array}{l}\text { Before } \\
\text { treatment } \\
(\mu \mathrm{mol} / \mathrm{l})\end{array}$ & $\begin{array}{l}\text { After } \\
\text { treatment } \\
(\mu \mathrm{mol} / \mathrm{l})\end{array}$ & $p^{*}$ \\
\hline \multicolumn{4}{|c|}{ Epithelial lining fluid: } \\
\hline $\begin{array}{l}\text { Total } \\
\text { glutathione }\end{array}$ & $160(16)$ & $\begin{array}{l}1 \text { hour: } 520(132) \\
2 \text { hours: } 294(56) \\
3 \text { hours: } 269(41)\end{array}$ & $\begin{array}{l}<0.005 \\
<0.005 \\
<0.005\end{array}$ \\
\hline $\begin{array}{l}\text { Reduced } \\
\text { glutathione }\end{array}$ & $153(15)$ & $\begin{array}{l}1 \text { hour: } 282(56) \\
2 \text { hours: } 223(27) \\
3 \text { hours: } 138(53)\end{array}$ & $\begin{array}{l}<0.005 \\
<0.05 \\
>0.9\end{array}$ \\
\hline $\begin{array}{l}\text { Oxidised } \\
\text { glutathione }\end{array}$ & $7(1)$ & $\begin{array}{l}1 \text { hour: } 239(83) \\
2 \text { hours: } 72(43) \\
3 \text { hours: } 131(69)\end{array}$ & $\begin{array}{l}<0.005 \\
<0.005 \\
<0.005\end{array}$ \\
\hline \multicolumn{4}{|l|}{$\begin{array}{l}\text { Plasma: } \\
\text { Total }\end{array}$} \\
\hline $\begin{array}{l}\text { glutathione } \\
\text { Reduced }\end{array}$ & $2 \cdot 11(0 \cdot 27)$ & $3.08(0.54)$ & $>0.05$ \\
\hline $\begin{array}{l}\text { glutathione } \\
\text { Oxidised }\end{array}$ & $2 \cdot 08(0 \cdot 27)$ & $2 \cdot 9(0.48)$ & $>0.05$ \\
\hline glutathione & $0.03(0.02)$ & $0.18(0 \cdot 14)$ & $>0.3$ \\
\hline
\end{tabular}

*All values after treatment compared with before treatment. For normal values see reference 8 . 
T LYMPHOCYTE PROLIFERATION ASSAYS

The cytotoxic lymphocyte cell line CT-4R increased proliferation from 7478 (550) cpm after incubation with the pretreatment concentration of $150 \mu \mathrm{mol} / 1$ reduced glutathione to 10752 (376) $\mathrm{cpm}$ after incubation with the post-treatment concentration of 280 $\mu \mathrm{mol} / 1$ reduced glutathione $(\mathrm{p}<0.01)$. Similarly, the cytotoxic lymphocyte cell line CTLL-2 increased proliferation from 5077 (69) $\mathrm{cpm}$ in $150 \mu \mathrm{mol} / 1$ reduced glutathione to $5792(219) \mathrm{cpm}$ in $280 \mu \mathrm{mol} / 1 \mathrm{reduced}$ glutathione $(\mathrm{p}<0.05)$.

\section{Discussion}

Several factors suggest that augmentation of glutathione concentrations in lung epithelial lining fluid could be beneficial for HIV seropositive individuals. Firstly, HIV infection is characterised by a systemic glutathione deficiency. ${ }^{8}$ Since pulmonary opportunistic infections are a leading cause of morbidity and mortality in AIDS, and since glutathione plays an important part in modulating immune cell function, ${ }^{812-15}$ augmentation of deficient glutathione levels may directly improve pulmonary host defence. In this regard, both cytotoxic $\mathrm{T}$ lymphocyte lines evaluated showed improved proliferation after in vitro glutathione levels were augmented from preaerosol to postaerosol lung epithelial lining fluid concentrations.

Secondly, an increased production of oxidants from inflammatory cells has been proposed to contribute to immune dysfunction in HIV infection. ${ }^{81825-29}$ Extracellular oxidants impair natural killer cell activity, interfere with the differentiation of $B$ cells into plasma cells, cause DNA strand breaks in lymphocytes, and suppress lymphocyte proliferation in response to mitogens. ${ }^{9-15} 3031$ Since reduced glutathione functions as a major antioxidant, ${ }^{671920}$ and since the administration of glutathione is helpful in experimental disorders of other organs associated with an increased oxidant burden, ${ }^{32-34}$ increasing antioxidant protection by augmentation of deficient glutathione levels in lung epithelial lining fluid may help to prevent oxidant damage to the immune cells of the respiratory host defence system. The aerosolisation process itself does not cause oxidation of reduced glutathione-that is, the conversion of the aerosolised reduced glutathione in epithelial lining fluid to an oxidised form indicates that it was probably functioning as an antioxidant.

Finally, intracellular glutathione deficieny may contribute to increased HIV replication, thereby increasing dysfunction of the immune system. Recent observations indicate that the in vitro extracellular addition of glutathione, glutathione ester, or $\mathrm{N}$-acetylcysteine to $\mathrm{HIV}$ cell cultures slows viral replication in both lymphocyte and monocyte cell lines, and prevents activation of viral replication by tumour necrosis factor $a$ and interleukin 6.16173536 Other thiol compounds such as penicillamine and 2,3-dimercaptopropanolol also inhibit
HIV replication. ${ }^{37} 38$ Augmentation of extracellular glutathione may have similar effects since extracellular glutathione can be degraded and resynthesised within cells - that is, augmentation of extracellular glutathione will augment intracellular glutathione, the principal intracellular thiol. ${ }^{6739}$

This study represents a first step in the evaluation of aerosolised glutathione as a potential treatment for HIV infection. It does not show clinical efficacy such as a reduction in the incidence of pulmonary opportunistic infections. It also does not evaluate the exact pattern of deposition of glutathione in the lungs. A poor deposition of the aerosol in the upper lung zones resulting from the position of the subjects during inhalation may lead to compartmentalisation of the immune and antioxidant effects of glutathione, as has been seen with inhaled pentamidine. ${ }^{40}$ This study, however, clearly demonstrates the feasibility and safety of the use of aerosolised glutathione in augmenting the deficient glutathione levels in the lower respiratory tract of HIV seropositive individuals, suggesting that a larger scale trial to evaluate the efficacy of this tripeptide in improving host defence and preventing opportunistic infections in HIV seropositive individuals is indicated.

We thank Dr W Robinson and Dr C Jolley for their help with the pulmonary function studies, and $\mathrm{Dr} W$ Paul for providing the CT-4R and CTLL-2 cell lines.

Dr Roland Buhl is a Fellow of the International Molecular Medicine Foundation.

1 Levy JA, ed. AIDS: pathogenesis and treatment. New York Marcel Dekker, 1990.

2 Murray JF, Mills J. Pulmonary infectious complications of human immunodeficiency virus infection. $A m$ Rev Respir Dis 1990;141:1356-72.

3 Rosenberg ZF, Fauci AS. Immunopathogenesis of HIV infection. FASEB f 1991;5:2382-90.

4 Levy JA. Mysteries of HIV: challenges for therapy and prevention. Nature 1988;333:519-22.

5 Edelman AS, Zolla-Panzer S. AIDS: a syndrome of immune dysregulation, dysfunction, and deficiency. FASEB f 1989;3:22-30.

6 Meister A, Anderson ME. Glutathione. Ann Rev Biochem 1983;52:711-60.

7 Meister A. Glutathione metabolism and its selective modification. $\mathcal{F}$ Biol Chem 1988;263:17205-26.

8 Buhl R, Jaffe HA, Holroyd KJ, Wells FB, Mastrangeli A, Saltini C, et al. Systemic glutathione deficiency in $N$ symptom-free HIV-seropositive individuals. Lancet 1989;ii:1294-8.

9 Carson DA, Seto S, Wasson DB. Lymphocyte dysfunc- N tion after DNA damage by toxic oxygen species. $\mathcal{F} \operatorname{Exp}$ Med 1986;163:746-51.

10 El-Hag A, Lipsky PE, Bennett R, Clark RA. Immunodulation by neutrophil peroxidase and hydrogen peroxide: differential susceptibility of human lym- $\Theta$ phocyte functions. F Immunol 1986;136:3420-6.

11 Stagnaro $R$, Pierri I, Piovano $P$, Baracco F, De Palma $M, T$ Indiveri $F$. Thiol containing antioxidant drugs and the $O$ human immune system. Bull Eur Physiopathol Respir $\mathbb{D}$ 1987;23:303-7.

12 Suthanthiran M, Anderson ME, Sharma VK, Meister A. Glutathione regulates activation dependent synthesis in highly purified normal human $\mathrm{T}$ lymphocytes stimulated via the CD2 and CD3 antigens. Proc Natl Acad Sci USA 1990;87:3343-7.

13 Messina JP, Lawrence DA. Cell cycle progression of glutathione-depleted human peripheral blood mononuclear $\vec{c}$ cells is inhibited at $\mathrm{S}$ phase. $f$ Immunol 1989; 143: 1974-81.

14 Liang C-M, Lee N, Cattell D, Liang S-M. Glutathione regulates interleukin-2 activity on cytotoxic T-cells. $\mathcal{F}$ Biol Chem 1989;264:13519-23.

15 Liang C-M, Liang S-M, Henry S, Epstein JS. Glutathione regulates CD4 and CD8 expression in murine splenic 
lymphocytes. Sixth International Conference on AIDS 1990;366 (Abstract)

16 Roederer M, Staal FJT, Raju PA, Ela SW, Herzenberg LA, Herzenberg LA. Cytokine-stimulated human immunodeficiency virus replication is inhibited by $\mathrm{N}$ acetyl-cysteine. Proc Natl Acad Sci USA 1990; 87:4884-8.

17 Kalebic T, Kinter A, Poli G, Anderson ME, Meister A, Fauci AS. Suppression of human immunodeficiency virus expression in chronically infected monocytic cells by glutathione, glutathione ester, and $\mathrm{N}$-acetylcysteine. Proc Natl Acad Sci USA 1991;88:1906-10.

18 Staal FJT, Ela SW, Roederer $M$, Anderson MT, Herzenberg LA, Herzenberg LA. Glutathione deficiency and human immunodeficiency virus infection. Lancer 1992;339:909-12.

19 Cantin AM, North SL, Hubbard RC, Crystal RG. Normal alveolar epithelial lining fluid contains high levels of glutathione. $₹$ Appl Physiol 1987;63:152-7.

20 Heffner JE, Repine JE. Pulmonary strategies of antioxidant defense. Am Rev Respir Dis 1989;140:531-54.

21 Wendel A, Cikryt P. The level and half-life of glutathione in human plasma. FEBS Lett 1980;120:209-11.

22 Buhl R, Vogelmeier C, Crittenden M, Hubbard RC, Hoyt RF, Wilson EM, et al. Augmentation of glutathione in the fluid lining the epithelium of the lower respiratory tract by directly administering glutathione aerosol. Proc Natl Acad Sci USA 1990;87:4063-7.

23 Saltini C, Hance AJ, Ferrans VJ, Basset F, Bitterman PB, Crystal RG. Accurate quantification of cells recovered by bronchoalveolar lavage. Am Rev Respir Dis 1984; by broncho:

24 Rennard SI, Basset G, Lecossier D, O'Donnell KM, Pinkston P, Martin PG, et al. Estimation of volume of epithelial lining fluid recovered by lavage using urea as marker of dilution. F Appl Physiol 1986;60:532-8.

25 Sonnerborg A, Jarstrand C. Nitroblue tetrazolium (NBT) reduction by neutrophilic granulocytes in patients with HTLV-III infection. Scand $\mathcal{F}$ Infect Dis 1986;18:101-3.

26 Sonnerborg A, Carlin G, Akerlund B, Jarstrand C. Increased production of malionaldehyde in patients with HIV infection. Scand f Infect Dis 1988;20:287-90.

27 Gougerot-Pocidalo $M-A$, Levacher $M$. Glutathione and HIV infection (letter). Lancet 1990;i:235.

28 Dupuy J-M, Revillard J-P, Hersh EM, El Habib R,
Caraux J. Glutathione and HIV infection (letter). Lancet 1990;i:236.

29 Halliwell B, Cross CE. Reactive oxygen species, antioxidants, and acquired immunodeficiency syndrome-sense or speculation? Arch Intern Med 1991;151:29-31.

30 Stacey NH, Craig GK Role of thiols in human peripheral blood natural killer and killer lymphocyte activities. Experientia 1989;45:180-1.

31 Hoffeld JT, Oppenheim JJ. Enhancement of the primary antibody response by 2 -mercaptoethanol is mediated by its action on glutathione in the serum. Eur $f$ Immunol 1980;10:391-5.

32 Paller MS, Sikora JJ. Hypothyroidism protects against free radical damage in ischemic acute renal failure. Kidney Int 1986;29:1162-6.

33 Yoda $Y$, Nakazawa M, Abe T, Kawakami Z. Prevention of doxorubicin myocardial toxicity in mice by reduced glutathione. Cancer Res 1986;46:2551-6.

34 Singh A, Lee K, Goldfarb R, Tsan MF. Glutathione protects against myocardial reperfusion injury. Clin Res 1988;36:318A (Abstract).

35 Folks TM, Clouse KA, Justement J, Rabson A, Duh E, Kehrl JH, et al. Tumor necrosis factor $\alpha$ induces expression of human immunodeficiency virus in a chronically infected T-cell clone. Proc Natl Acad Sci USA 1989; 86:2365-8.

36 Roederer M, Ela SW, Staal F, Herzenberg LA, Herzenberg LA. $N$-acetyl-cysteine: a new approach to anti-HIV therapy. AIDS Res Hum Retrovir 1992, 8:209-17.

37 Chandra A, Demirhan I, Arya SK, Chandra P. D-penicillamine inhibits transactivation of human immunodeficiency virus type-1 (HIV-1) LTR by transactivator protein. FEBS Lett 1988;236:282-6.

38 Kubota S, El-Farrash MA, Maki M, Harada S, Hatanaka M. 2,3 dimercapto-1-propanolol inhibits HIV-1 tat activity, viral production, and infectivity in vitro. AIDS Res Hum Retrovir 1990;6:919-27.

39 Bannai S, Tateishi N. Role of membrane transport in metabolism and function of glutathione in mammals. $f$ Membr Biol 1986;89:1-8.

40 Bradburne RM, Ettensohn DB, Opal SM, McCool FD. Relapse of $P$ carinii pneumonia in the upper lobes during aerosol pentamidine prophylaxis. Thorax 1989; 44:591-3. 